Historic, Archive Document

Do not assume content reflects current scientific knowledge, policies, or practices. 



\title{
TRADE PRICE LIST SPRING 1927
}

\section{J. JENKINS \& SON COLUMBIANA CO. WINONA, - OHIO}

\author{
References: \\ First Nat'l Bank, Salem, Ohio \\ and Commercial Agencies
}

\section{NURSERIES ESTABLISHED}

1864

\section{TERMS:}

Cash before Shipment. Three hundred at 1000 rates, 25 at hundred rates. Shipments travel at buyers risk. We disclaim all responsibility after delivery to forwarding company.

C. O. D. orders must be accompanied by one-fourth cash. Parcel Post orders must be accompanied by sufficient funds to cover postage. Any balance received and not used for this purpose will be refunded immediately when shipment is made.

Prices are net, packing additional cost.

Ask for Sample page of book, "Art of Propagation." 
Abies balsamea, Balsam Fir 2 yr. sdg.

" " " trans.

in. $\$ 2.00$

$\$ 15.00$

" fraseri, Fraser's fir 2 yr. sdg.

3-6

in. 7.00

60.00

Larix europea, European larch sdg.

$1-2$ in. $4.00 \quad 35.00$ $" \quad "$

" " " " " "

$2-4$ in. 1.50

Picea alba, White spruce sdg..

4-6 in. $2.00 \quad 12.00$ ss 2,

צ'

,

9

9,

trans.

6-12 in.

3.00

4.00

$2-18$ in

20.00

Picea excelsa, Norway spruce sdgs

$"$ " " " " "

Pinus austriaca, Austrian pine sdg $2-4$ in

1.50

35.00

2.00

10.00

4-6 in.

15.00

3.00

20.00

$2-3$ in. 3.00

20.00

30.00

9

ponderosa, West. yel. pine 2 yr

excelsa, Bhotan pine 2 yr. sdg.

banksiana, Jack pine sdgs

densiflora, Jap. red pine sdg.

$$
\text { “ “ “ “ }
$$$$
\text { ، }
$$

resinosa, Red pine sdgs

montana uncinata

mughus

"

....

sylvestris, Scotch pine sdg

",

,

,

9

"9

9

9

",

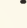

3-6

$2-4$

$4-6$

6-8

in.

1.00

8.00

in. $\quad 1.50$

12.00

3.00

25.00

2.00

10.00

2.50

$4-6$ in

15.00

1.00

6.00

$3.00 \quad 25.00$

6-12 in

4.00

20.00

4-6 in

5.00

40.00

1.00

5.00

4-6 in.

2.00

10.00

2-4 in

1.50

8.00

$2.00 \quad 15.00$

3.00

6-10 in.

4.00

30.00

3.50

25.00

2-4 in.

5.00

40.00

,9

,9

trans.

2-4 in.

1.00

5.00

2.00

10.00

$\begin{array}{ll}2.50 & 15.00\end{array}$

$3.00 \quad 20.00$

$3.50 \quad 25.00$

$4.50 \quad 35.00$

We have an exceptionally large stock of Scotch and Austrian Pine two and three

year seedlings. Let us quote you on 10 or 20 thousand lots.

" strobus, White Pine, 2 yr. sdg.

Pseudotsuga douglasi, Douglas fir "”

4-6 in.

$6-12$ in.

$"$ "

$2-4$ in

4.50

35.00

9

",

" "

$2-4$ in

2.00

10.00

6-8 in. $4.50 \quad 40.00$

Thuya occidentalis, Am. Arbor Vitae sdg.......... 2-4 in. 2.00 in.

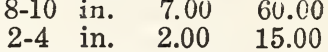

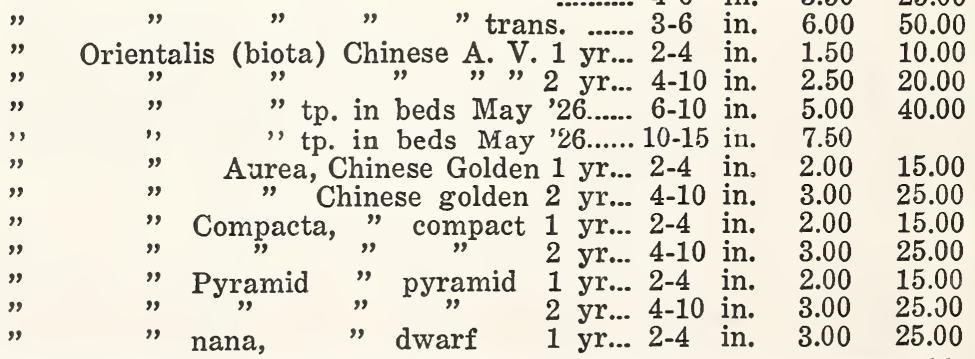

Although the seed of the different varieties of Chinese Arbor Vitae is selected with care from trees having the definite characteristics of the variety, on account of the possibility of variation in form, color, etc. we cannot guarantee them to develop the exact form for which they are named.

Tsuga canadensis, Hemlock spruce tran............. 3-6 in. $\$ 12.00$

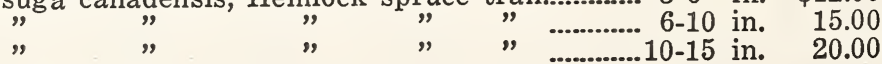


To those who wish one year evergreen seedlings we will make price on request. We have the following varieties: Picea excelsa, pungens, englemani, polita and alba, Pinus excelsa, austriaca, ponderosa, sylvestris, strobus, resinosa, montana, mughus, thunbergii, banksiana, densiflora and Mongolica. Larix europea and leptolis. Chamaecyparis obtusa, pisifera and Lawsoniana. Cryptomeria japonica, Abies balsamea and concolor, Thuya occidentalis.

\section{EVERGREENS}

Several time transplanted. Sheared. Priced with B. \& B. Abies balsamea, Balsam fir 12-18 in. each " " " 18-24 in. Juniperus hibernica, Irish Juniper........................ 2-3 ft. $\$ 1.25$

1.75

1.50

2.50

" pfitzeriana, Pfitzer's " 3-4 ft. $12-18$ in. sabina, Savin Juniper. 18-24 in.

1.25

2.00 stricta, Greek juniper. $10-12$ in. "

Picea alba, White Spruce ..

2.00

1.25

$"$ excelsa, Norway spruce................................... 18-24 in.

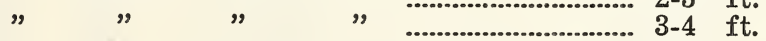

We can supply Norway Spruce in car lots

" pungens, Colorado spruce medium color 12-18 in. Pinus resinosa, Red pine..................................... 2-3 ft. Pseudotsuga douglasii, Douglas fir.....................12-18 in. $"$ " $" \ldots . . . . . . . . . . . . . .22-3$ ft.

Retinospora pisifera....................................................12-18 in.

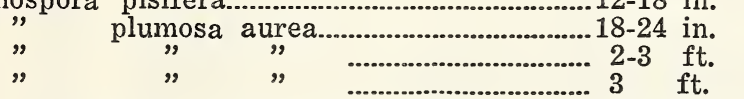

Thuya occidentalis, Am. Arbor Vitae...................12-18 in.

\section{8}

\section{9}

\section{,}

,

9

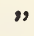

9

$n$
",
,
,

$" \quad "$

,

$"$

$2-3 \mathrm{ft}$

Compacta, Compacta A. V...24-30 ft. spd. hoveyii, Hovey's A. V..........10-12 in. lutea, Peabody's gol. A. V.12-18 in.

1.50

2.25

The

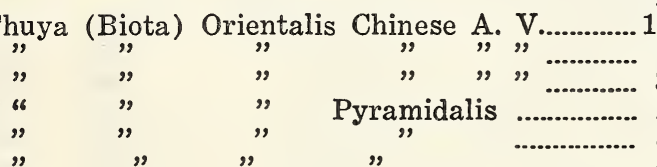

Thuya Orientalis-aurea-Nana,

\section{Berckmans Golden} "

Tsuga candensis, Hemlock spruce. "

,

,

,

18-24 in

2-3 ft.

$3 \mathrm{ft}$.

$2-3 \mathrm{ft}$.

3-4 ft.

$4 \mathrm{ft}$.

3.00

1.00

1.00

1.75

2.50

1.50

2.00

3.00

2.00

3.00

3.50

NURSERY GROWN TREE SEEDLINGS Size

Acer campestris, English maple.

" dasycarpum, Silver maple.

12 in.

2.50

2-3 ft.

2.50

3-4 ft.

4.00

4-5 ft.

6.00

$100 \quad 1000$

$2-4$ in. $\$ 4.00 \$ 35.00$

6-12 in. $2.00 \quad 10.00$

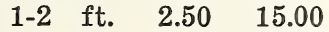

platanoides, Norway maple............................... $3-6$ in.

6-12 in.

2.00

15.00

$4.00 \quad 35.00$

saccharinum, Sugar maple.................................. 3-6 in. $\quad 1.50 \quad 8.00$

6-12 in. $2.00 \quad 12.00$

" $\quad " \quad$ " $\quad$..................... 12 in. \& up 4.00

We have nearly a million two year Sugar maple seedlings and can make you interesting prices on large quantities.

Aesculus glabra, Ohio Buckeye.

3-6 in. 4.00

30.00

Betula alba, Eup. white birch. 
Castanea dentata, Am. swt. chestnut.

Diospyros virginiana, Am. persimmon.

6-12 in.

2.00

15.00

Fraxinus americana, White ash

$6-12$ in. $2.00 \quad 15.00$

White ash is recommended by some as the best understock for Li

.50

3.00

$3.00 \quad 25.00$ is valuable. It makes quick and good shade.

Gymnocladus canadensis, $\mathrm{Ky}$. coffee..

Juglans cinerea, White Walnut.

6-12 in.

6-12 in.

5.00

40.00

", nigra, Black Walnut.

$2-3 \mathrm{ft}$.

2.00

10.00

Liriodendron tulipifera, Tulip tree.

6-12 in.

3.50

2.00

3.50

$3-6$ in

10.00

2.00

6-12 in.

"

,

" "

12-18 in.

3.00

10.00

Magnolia acuminata, Cucumber tree.

Nyssa sylvatica, Sour gum.

Quercus alba, White oak.

3-6 in.

4.00

20.00

7.50

2.00

4.00

3.00

4.00

4.00

Sorbus Acuparia Mt. Ash... 3-6 in

6-12 in.

Tilia americana, Am. linden

6-9 in.

8.00

18-24 in.

3.50

10.00

30.00

20.00

30.00

30.00

"6

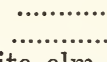

4-6 in.

Ulmus americana, Am. white elm

6-12 in.

5.C0

30.00

.50

40.10

1.00

3.00

6-12 in.

2.00

We have an excellent supply of Elm seedlings. Write us for prices in quantity.

Salix elegantissima, Weeping willow.................. 6-12 in.

$2.50 \quad 20.00$

,"

babyonica, weeping willow

12-18 in.

3.50

25.00

$2.50 \quad 20.00$

", "

6-12 in

3.50

25.00

",

")

$2-3 \mathrm{ft}$.

5.00

40.00

\section{SHRUBS FOR LINING OUT}

L. layers S. seedlings $H$. C. rooted cuttings. tp. transplants Althea rosea, Rose of Sharon ...................... 6-12 in. $\$ 2.00 \quad \$ 10.00$ Berberis thunbergi, Japan Barberry S................. 6-9 in. $2.00 \quad 15.00$ " " " " "............ 9-12 in. $2.50 \quad 20.00$ Cornus alba siberica, Coraldogwood, H. C..........12-18 in. $\quad 5.00 \quad 40.00$

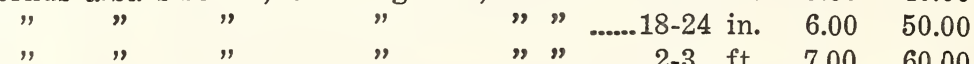

Cornus Baileyii ....................................................12-18 in. 7.50

$7.00 \quad 60.00$

$2.00 \quad 15.00$

$3.00 \quad 20.00$

$4.00 \quad 30.00$ $\begin{array}{llll}\text { stolonifera flaviramea, Yel. bark H. C. } 6-12 \text { in. } & 6.00 & 50.00 \\ \text { stolonifera flaviramea, Yel. bark H. C. } 12-18 \text { in. } & 7.00 & 60.00\end{array}$ stolonifera flaviramea, Yel. bark H. C. 12-18 in. $7.00 \quad 60.00$

Deutzia Crenata, Crinkle deutzia, „H., „............. 6-12 in. $4.00 \quad 30.00$ Pride of Rochester H. C......................... 6-12 in.

$4.00 \quad 30.00$

$5.00 \quad 40.00$

Forsythia fortuna, Fort. golden bell H. C......... 3-6 in. $2.00 \quad 15.00$

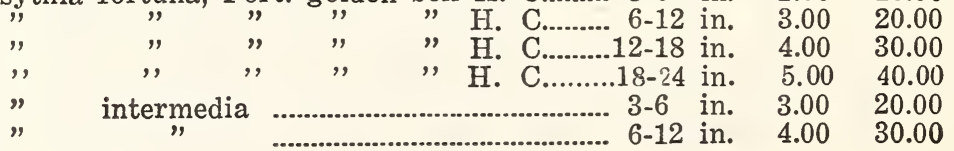



Hydrangea Paniculata grand. H. C

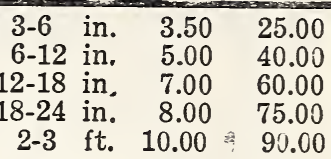

We recommend our Hydrangea P. G. They are all the strong growing strain.

No dwarfs. They have been fertilized and are stocky well rooted plants.

Spirea billardi rosea $\mathrm{H}_{,}$, C

" opulifolia aurea H.

",

.

6-12 in, 5.00

40.00

,

$"$

" "

,",

1824 in 4.00

30.00

$2-3$ ft. $\quad 5.00 \quad 40.00$

$"$

,

9

32

6-12 in.

2.50

$3.50 \quad 25.00$

Spirea reevesiana $\mathrm{H}$. C.

12-18 in.

18-24 in.

$4.00 \quad 30.00$

$5.00 \quad 40.00$

"
"
"
"
"

$3-6$ in.

5.00

6-12 in.

6.00

4.00

40.00

3-6 in.

6-12 in.

5.00

50.00

12-18 in.

4.00

30.00

18-24 in.

5.00

b. 00

Viburnum Op. Sterilis, Com. snowball L........... 3-6 in

50.10

\begin{tabular}{|c|c|c|c|c|}
\hline " & " & $"$ & "s. "sise & " \\
\hline$"$ & $"$ & $"$ & $"$ & \\
\hline " & plicatum, & Japan & snowball I & 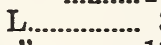 \\
\hline " & $"$ & ") & $"$ & $"$. \\
\hline$"$ & $"$ & $"$ & $"$ & 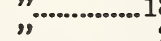 \\
\hline$"$ & $"$ & $"$ & "H. C & 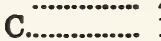 \\
\hline ", & $"$ & $"$ & $" \|$ &,$\ldots$ \\
\hline
\end{tabular}

$12-18$ in.

5.00

8.50

$18-24$ in. 10.00

3-6 in. 5.00

40.00

35.00

SHRUBS

12-18 in

8.50

$8-24$ in. 11.00

$2-3$ ft. 15.00

$1-3$ in. 4.00

$3-6$ in. 6.00

40.00

75.00

90.00

40.00

75.00

100.00

30.00

50.00

All transplanted one or more times.

40 Amorpha fruiticosa.

100

8 Aralia Pentaphilla.

(1)................................... 2-3 ft.

2.00

.75

1.50

$" \quad \ldots \ldots \ldots \ldots . . \cdots 12-18$ in.

")

9

"

28

$"$

"

Box Barberry, bushy

"

$2-3 \mathrm{ft}$.

2.00

2.50

3.50

2.50

Buddleia magnifica, Butterfly bush 18-24 in.

Two year tops cut back

Cornus alba siberica, Coral Dogwood..................12-18 in.

" florida branched low

$2-3 \mathrm{ft}$.

sanguinea, Eng. red branched

$4-5 \mathrm{ft}$.

Clethra alnifolia, Swt. pepper bush

$12-18$ in.

1.50

2.00

1.75

3.00

2.00

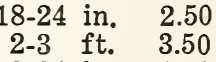

$18-24$ in. 2.50
$2-3$ ft. 3.50

"

Deutzia candidissima, white deutzia......................18-24 in.

2.00

1.00

1.50

$18-24$ in.

$2-3 \mathrm{ft}$.

2.00

2.50

1.00

1.50

12-18 in.

Pride of Rochester.

18-24 in.

$2-3 \mathrm{ft}$.

2.00

$\begin{array}{lll}3-4 & \mathrm{ft} . & 2.50 \\ 1-2 & \mathrm{ft} & 75\end{array}$

Forsythia fortuna, Fortunes Gol. bell.................. 1-2 1 ft.

1.00

1.00 6-12 in. 
Hydrangea arb. grandiflora

Hydrangea Paniculata grand

12-18 in.

$"$ " $" \#$ "

1.00

2.50

Lonicera morrowi, Morrows honeysuckle...

$2-3 \mathrm{ft}$.

3.00

7.00

15.00

$2-3 \mathrm{ft}$.

2.00

25.00

" tartarica

2.50

15.00

Philadelphus Mont blan

3-4

$\mathrm{ft}$.

2.50

20.00

20.00

10 Rhodotyphus kerroides

$3-4$ ft. 2.00

3.00

15.00

Spirea anthony waterer.

4-5 ft.

3.50

2.50

1.50

$12-18$ in.

" billardi rosea.................................................18-24 in

$" \quad " \quad$ ".................................................. 2-3 ft.

" alba ............................................. 3-4 ft.

" calosa alba...

$12-18$ in.

froebelli

$2-3 \mathrm{ft}$.

,

Van Houtei

18-24 in.

$2-3 \mathrm{ft}$.

Size

Spirea opulifolia, Ninebark.

2-3 ft.

3-4 ft.

$"$

,

aurea

$12-18$ in.

18-24 in.

" reevesiana

6-12 in.

$"$

$"$

$$
\text { " }
$$

$2-18$ in

18-24 in.

$10 "$ thunbergii

18-24 in.

Symphoricarpus vulgaris, Coralberry.................. 6-12 in.

Stephanandra flexuosus..

12-18 in.

Viburnum Op. Sterilis, Common Snowball 12-18 in.

2.00

2.00

2.50

3.00

2.00

2.50

10

20.00

1.00

1.50

1.00

1.50

1.00

1.50

2.00

3.00

.75

1.50

3.50

3.00

4.00

2-3 ft.

5.00

$6 "$ dentatum bushy.................................... 3-5 3 ft.

Weigelia eva Rathke.

$18-24$ in.

6.00

4.00

100

Ampelopsis quinquefolia

Clematis paniculata.

1 yr. .50

Asparagus, Conovers colossal.

$1 \mathrm{yr}$.

$\$ 4.00$

.75

1.00

10.00

15.00

15.00

15.00

20.00

100

8.00

10.00

8.00

10.00

8.00

10.00

15.00

5.00

10.00

1.00

1.50

2.50

2.00

2.00

2.50

1.50

5.00

3.50

1000

Red Raspberry suckers, marlboro

Black Raspberry tips, Plum Farmer \& Kansas

Yucca Filamentosa 2 yr. trans

No. 2 grade

Hibiscus, Giant mallows, 2 yr. trans. Red........

6 Prunus pissardi, Purple leaf plum ......1 yr. $\$ 7.50$

6 "Newport, Red leaf plum.1 yr. 2-3 ft. 10.00

$15 "$ " " 1 yr. 4-5 ft. 15.00

50 Currants No. 1........................................3 yr. $\quad .75$

London Market, Red Cross \& Wilder.

4 Camperdown Elm 3 yr. heads.

$\$ 3.00$ each

One year Peach trees, prices on application.

\section{TREE SEEDS}

Ib.

Magnolia acuminata, Cucumber tree...................

Prunus serotina, Black Cherry..............................

Nyssa sylvatica, Sour gum.

Picea excelsa, Norway Spruce, sweedish origin

Betula Alba, Eup. White Birch 
